\title{
SOME GEOLOGICAL OBSERVATIONS IN SLOVAČKA JAMA CAVE (-1268 m) IN VELEBIT MOUNTAIN, CROATIA
}

\author{
GEOLOŠKA ZAPAŽANJA IZ "SLOVAŠKE JAME" \\ (-1268 m) NA VELEBITU (HRVAŠKA)
}

DAMIR LACKOVIĆ ${ }^{1} \&$ BRANISLAV ŚMIDA $^{2} \&$

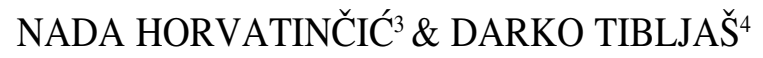

${ }^{1}$ Croatian Natural History Museum, Demetrova 1, ZAGREB, CROATIA.

${ }^{2}$ Slovak Speleological Society, BRATISLAVA, SLOVAKIA.

${ }^{3}$ Ruđer Bošković Institute, Bijenička c. 54, ZAGREB, CROATIA.

${ }^{4}$ Institute of Mineralogy and Petrography, Dept. of Geology, Faculty of Science, University of Zagreb, Horvatovac bb., ZAGREB, CROATIA. 
UDK: 551.44(497.5)

\section{Damir Lacković \& Branislav Šmida \& Nada Horvatinčić \& Darko Tibljaš: Geološka zapažanja iz "Slovaške jame" (-1268 m) na Velebitu (Hrvaška)}

Tekom zadnjih treh speleoloških odprav je bila Slovaška jama raziskana do globine $1268 \mathrm{~m}$. V njej je več rovov freatičnih oblik. Hipsometrično najvišji ostanki takih rovov so najbrž v zvezi s ponori iz časa, ko je nastajala uvala Veliki Lubenovac. Spodnji, recentni in subrecentni freatični horizonti v jamskem "dnu" so verjetno del kanalov podzemeljske reke Like, ki ponika na severovzhodni strani Velebita in teče skozenj v podmorske izvire v Jadranskem morju. Ostali rovi so predvsem brezna in meandri z vadoznimi oblikami. Analize izotopa ${ }^{14} \mathrm{C}$ dokazujejo, da so najstarejše sige v obojih, v starih in v subrecentnih freatičnih rovih, medtem ko so mlajše sige $\mathrm{v}$ vadoznih meandrih.

Ključne besede: speleomorfologija, freatični rov, ${ }^{14} \mathrm{C}$ datacija, dinarski kras, Velebit, Hrvaška.

\section{Abstract}

UDC: $551.44(497.5)$

\section{Damir Lacković \& Branislav Šmida \& Nada Horvatinčić \& Darko Tibljaš: Some geological observations in Slovačka jama cave $\mathbf{( - 1 2 6 8 m )}$ in Velebit mountain, Croatia}

During three speleological expeditions the Slovačka jama cave has been explored to the depth of $1268 \mathrm{~m}$. In the cave there are several channels with phreatic forms. The highest relict phreatic channel is probably due to sinkholes formed on the karst uvala Veliki Lubenovac at the time of uvala formation. Lower, recent and subrecent, phreatic horizons at the cave bottom are probably a part of the underground route of the Lika river which sinks on the north-eastern side of Velebit mountain and flows through the mountain to the submarine springs in the Adriatic sea. Other channels are mostly shafts and channels with meandering vadose forms. ${ }^{14} \mathrm{C}$ isotope analysis of speleothems shows that the oldest are situated in both ancient and subrecent phreatic channels, while younger ones are found in the vadose meandering channel.

Key words: spelomorphology, freatical channel, ${ }^{14} \mathrm{C}$ datation, Dinaric karst, Velebit Mt., Croatia. 


\section{INTRODUCTION}

Slovačka jama is situated in the northern part of Velebit mountain in Croatia (Fig. 1). This area is part of the Outer Dinaric belt which is characterised by several-kilometre-thick platform carbonates (Herak et al., 1970).

In the surrounding area are situated the Lukina jama - Trojama cave system (depth: $1392 \mathrm{~m}$, the deepest cave in Croatia), Patkov gušt (depth: 553m) and Ledena jama (depth: 514m) (Fig. 2).

Slovakian speleologists named the Slovačka jama after their country in 1995, when they found the entrance and started exploration.

During two succeeding expeditions Slovakian and Croatian speleologists explored the cave to the depth of $1268 \mathrm{~m}$, and made some geological investigations.

The expedition in 1999 will continue explorations.

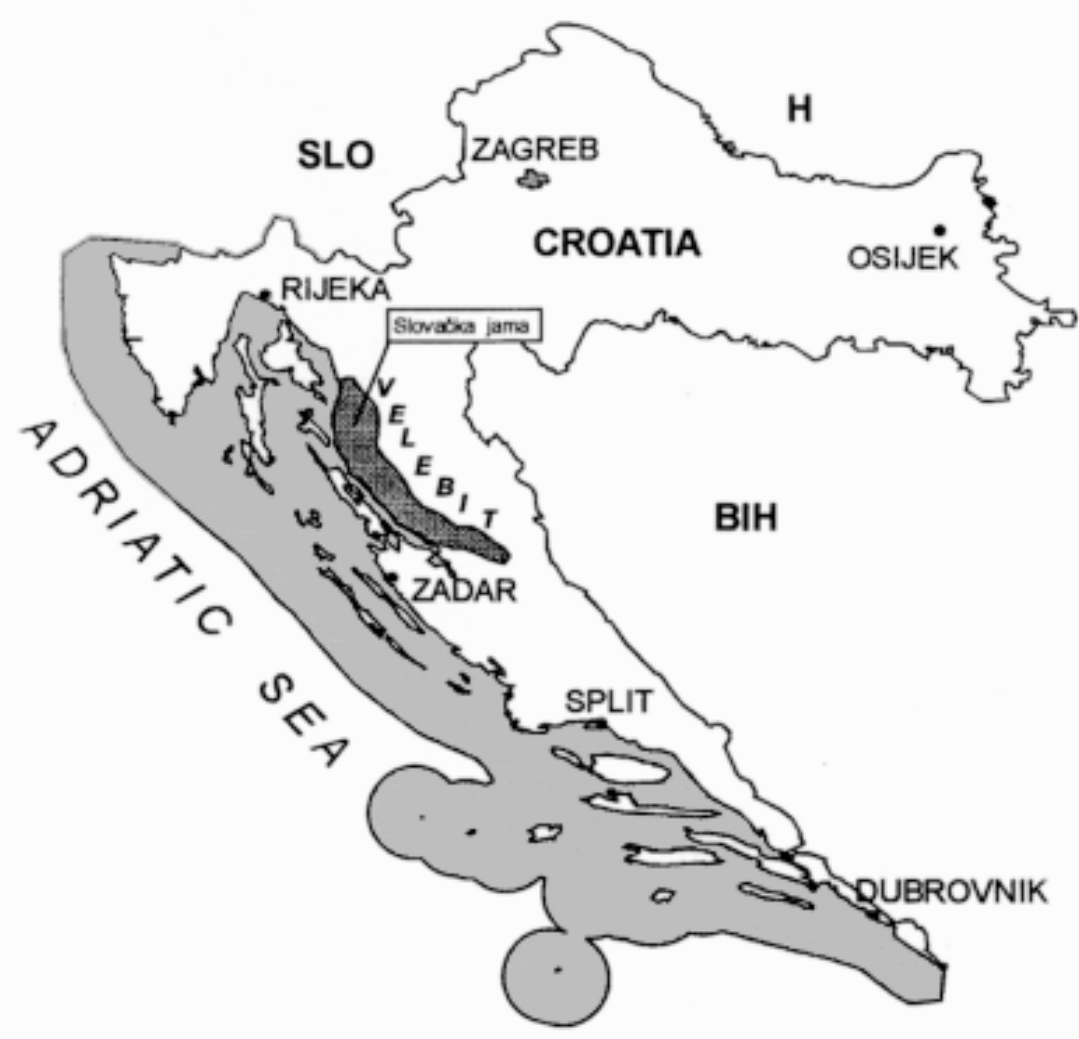

Fig. 1: The position of entrance to the Slovačka jama. 


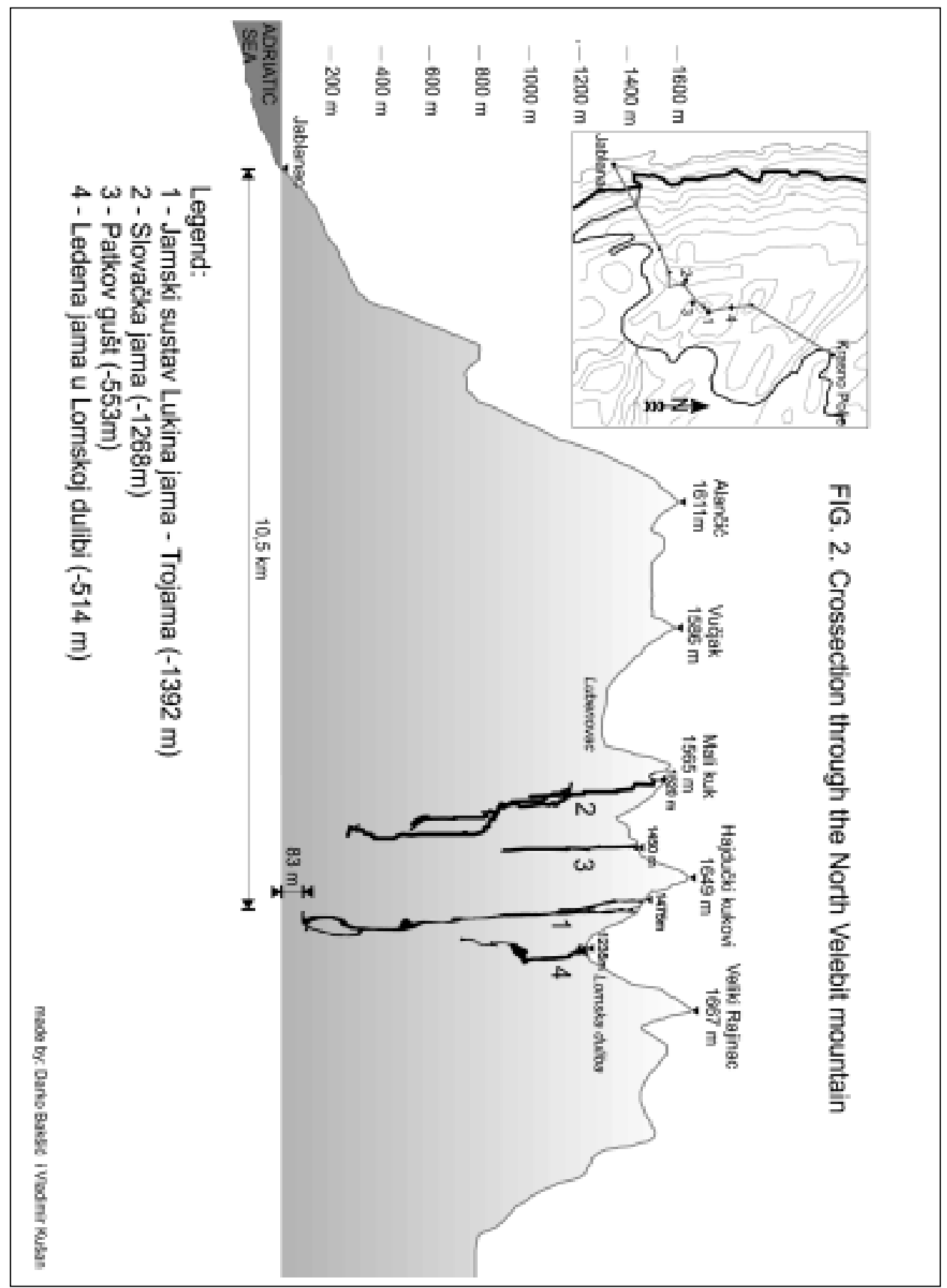

Fig. 2: Crossection trough the north Velebit mountain with profiles of Slovačka jama and other deep caves. 


\section{METHODS}

Several samples of speleothems were analysed by means of ${ }^{14} \mathrm{C}$ isotope analysis. One sample of fibrous crystals was identified by X-ray diffraction.

In the cave several bedding planes and fractures were measured, and some rocky relief features were observed.

\section{RESULTS}

\section{Cave morphology}

Generally, in Slovačka jama vadose shafts and meander forms of channels dominate.

Some channels have phreatic forms. One of them is situated at a depth of $350 \mathrm{~m}$ from the entrance (1170 $\mathrm{m}$ a.s.l.). Today it is a dry passage with very little vertical percolation of water. On the walls there are many relict potholes originating from a phreatic stage of channel formation (Fig. 3). On the walls recent white fibrous crystals, with the rare form of "cave cotton" (Hill and Forti, 1988), were also observed. X-ray diffraction revealed calcite. In some parts of the channel there is a several meters thick clay sediment.

Other phreatic form channels were recognised around the present bottom of the cave. The lower recent phreatic channel is situated at a depth of $1268 \mathrm{~m}-252 \mathrm{~m}$ a.s.l., and a higher subrecent phreatic channel is at $1254 \mathrm{~m}-266 \mathrm{~m}$ a.s.l. In the former, stalactites and stalagmites (Fig. 5-C) that formed in the vadose stage were found.

\section{Radiocarbon dates}

Stalactites from the horizontal relict phreatic passage at a depth of $350 \mathrm{~m}$ (Fig. 5-A) show an age of more than 37000 years.

Flowstone from the vadose meander channel at $625 \mathrm{~m}$ (Fig. 5-B) shows an age of $13600 \pm 370$ years.

Stalagmite at a depth of $1254 \mathrm{~m}$ (subrecent phreatic channel, Fig. 5-C) shows an age of $28000 \pm 3200$ years. Two stalactites from the same location are more than 37000 years old.

\section{DISCUSSION}

\section{Speleogenesis of the phreatic channels in Slovačka jama}

The relict phreatic channel at the depth of $350 \mathrm{~m}$ below the entrance (1170 $\mathrm{m}$ a.s.l.) is probably the oldest channel of the cave.

The phreatic conditions of this more or less horizontal channel existed probably before the formation of the vertical vadose shafts and meanders. Vadose speleothems are older than 37000 years, which means that speleothems formed in this channel are not a product of recent processes. The origin of the channel may be connected with the origin of uvala Veliki Lubenovac (1300 m a.s.l., Fig. 2) at the time of uvala formation. The channel may be a part of an underground waterway which drained the uvala. It may present local water table at the time of uvala formation. If vertical tectonic movements interrupted the channel another part of this phreatic conduit must be present elsewhere. In the ponor area of V. Lubenovac there are no known entrances to underground. 


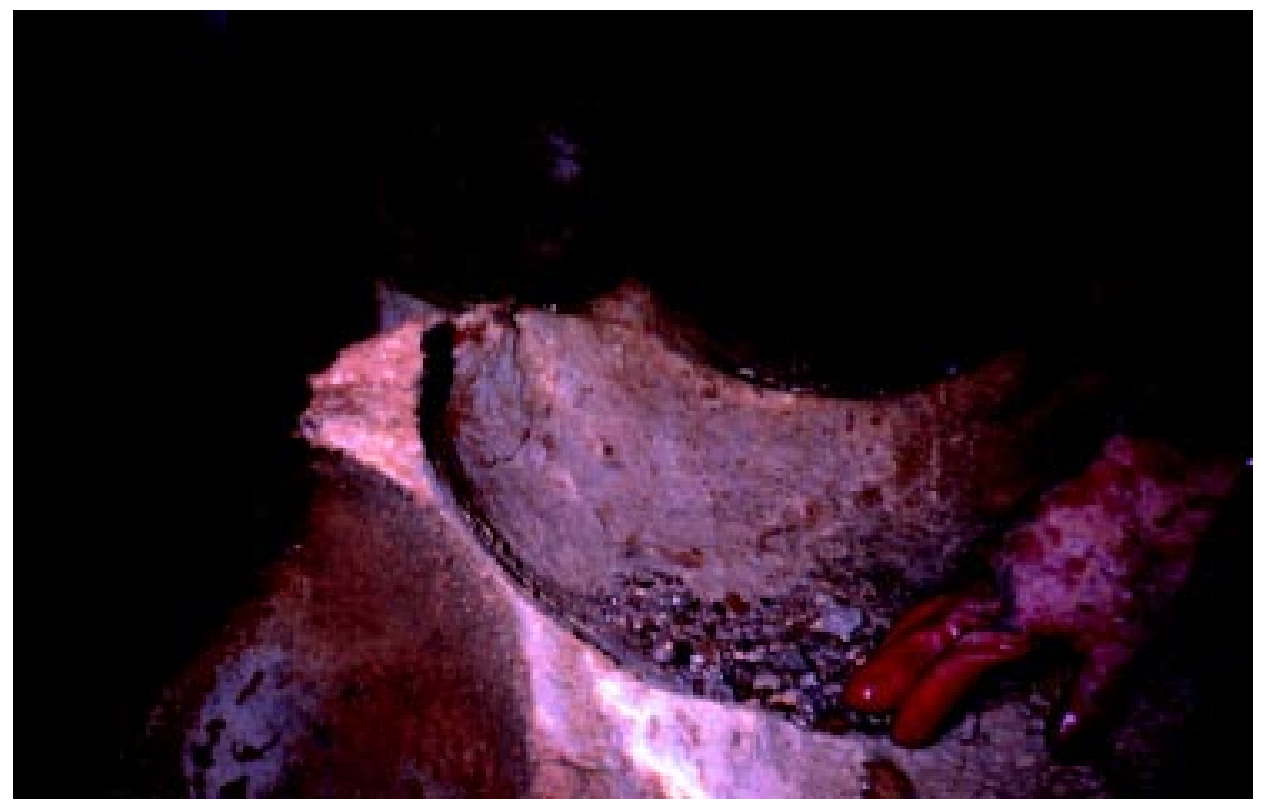

Fig. 3: Pothole in dry relict phreatic channel on the depth of $350 \mathrm{~m}$ (photo: D. Lacković). 


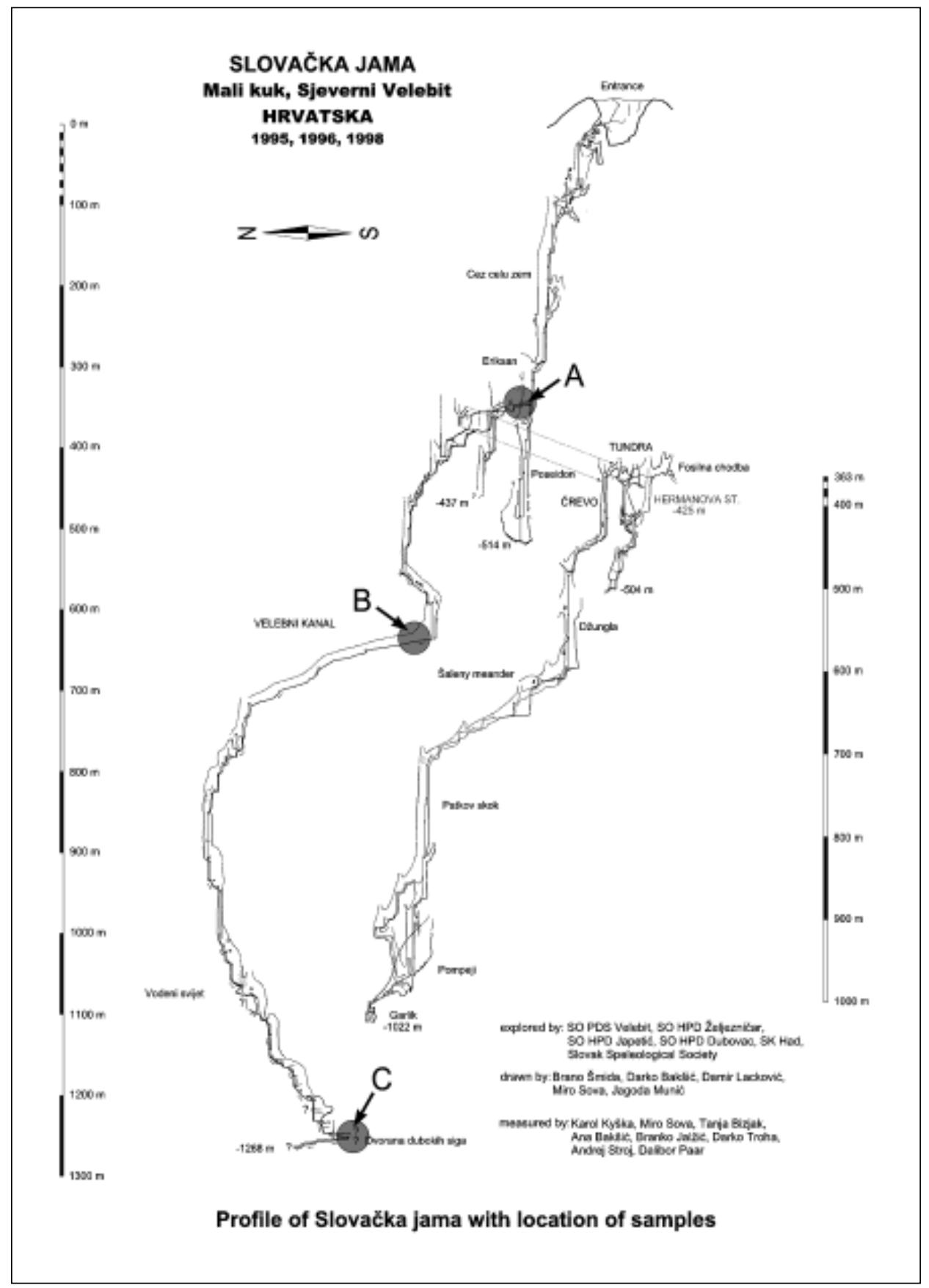

Fig. 5: Profile of Slovačka jama with location of samples for ${ }^{14} \mathrm{C}$ isotope analysis. 
Lower recent (at the cave bottom $1268 \mathrm{~m}$ deep - $252 \mathrm{~m}$ a.s.l.)) and subrecent (at the level of $1254 \mathrm{~m}$ - $266 \mathrm{~m}$ a.s.l.) phreatic horizons are probably part of underground waterway of ponor Lika river which sinks on the north-eastern side of Velebit mountain and flows through the mountain to the submarine springs in the Adriatic sea (Biondić \& Goatti, 1976). There is still a question whether the channel at the bottom is phreatic or phreatic/vadose. In the first case the channel would represent a local water table, and in the second case the channel may became really phreatic at greater depth, perhaps similar to the depth of phreatic channel in Lukina jama - Trojama cave system, at a level of $83 \mathrm{~m}$ a.s.l. The age of speleothems $14 \mathrm{~m}$ above the active channel at the bottom shows that the subrecent upper phreatic channel dried before the speleothems occurred ( $>37000$ years). It could present also the relative velocity of the lowering of the erosion base.

\section{LITERATURE}

Herak, M., Polšak, A., Gušić, I. and Babić, Lj., 1970. Dinamische und raumliche Sedimentationsbedingungen der mesozoischen Karbonatgesteine im Dinarischen Karstgebiet. Verhandlungen der Geologischen Bundesanstalt, 1970/4, 637-643, Wien.

Hill, C. \& Forti, P., 1997. Cave Minerals of the World. Nat. Spel. Soc. 463pp, Alabama.

Biondić, B. \& Goatti, V., 1976. Hidrogeološke prilike ponornih zona rijeke Like i Gacke i njihove podzemne veze s izvorima u Hrvatskom primorju. (Hidrogeologic conditions of ponors of Lika and Gacka rivers and their underground connections with springs in the Croatian littoral (in croat.) Zbornik radova 4. jugosl. simp. hidrogeol. inž. geol., 1, 1-14, 5 sl., Skopje.

\section{GEOLOŠKA ZAPAŽANJA IZ “SLOVAŠKE JAME” (-1268 m) NA VELEBITU (HRVAŠKA)}

\section{Povzetek}

Tekom zadnjih treh speleoloških odprav je bila Slovaška jama raziskana do globine $1268 \mathrm{~m}$. V jami prevladujejo vadozna brezna in meandri, je pa tudi več rovov z ohranjenimi freatičnimi oblikami. Prvi tak rov je že $350 \mathrm{~m}$ pod vhodom (1170 m n. m.) Hipsometrično najvišji ostanki takih rovov so najbrž v zvezi s ponori iz časa, ko je nastajala uvala Veliki Lubenovac. V njih so nastale redke oblike kalcita - "jamski bombaž”, ponekod pa so ohranjene tudi debele plasti gline. Spodnji, recentni in subrecentni freatični horizonti v jamskem "dnu” (najgloblji je v globini $1268 \mathrm{~m}$, le še $252 \mathrm{~m}$ nad morjem) so verjetno del kanalov podzemeljske reke Like, ki ponika na severovzhodni strani Velebita in teče skozenj $\mathrm{v}$ podmorske izvire $\mathrm{v}$ Jadranskem morju. Tudi $\mathrm{v}$ teh so sigove tvorbe, nastale $\mathrm{v}$ vadozni fazi razvoja. Ostali rovi so predvsem brezna in meandri z vadoznimi oblikami. Analize izotopa ${ }^{14} \mathrm{C}$ dokazujejo, da so najstarejše sige (stare več kot 37000 let) v obojih, v starih in v subrecentnih (28 $000 \pm 3200$ let) freatičnih rovih, medtem ko so mlajše sige (13 $600 \pm 370$ let $) \mathrm{v}$ vadoznih meandrih.

Starost kapnikov $14 \mathrm{~m}$ nad aktivnimi rovi na "dnu" govori za to, da so se subrecentni zgornji freatični kanali izsušili - prešli v vadozno fazo - preden so se pojavili ti kapniki (>37000 let). To lahko tudi kaže na relativno hitrost zniževanja erozijske baze. 